\title{
RETROSPECTIVE ANALYSIS OF CANINE MESENCHYMAL TUMORS OF SKIN AND SOFT TISSUES
}

\author{
ALEKSIĆ-KOVAČEVIĆ SANJA, KUKOLJ V, JELESIJEVIĆ T and JOVANOVIĆ M
}

Department of Pathology, Faculty of Veterinary Medicine, Belgrade

(Received 27. April 2005)

Out of the total number of 632 tumor specimens obtained from dogs of different breeds over the period of last 66 months, cutaneous tumors were diagnosed in 211 cases, i.e., in 123 (58.3\%) male dogs and $88(41.7 \%)$ bitches, aged on average 7 years. Among the total number of 211 skin tumors, 32 types of cutaneous neoplasms were diagnosed, with epithelial and melanocytic tumors being the most predominant (58.3\%), followed by hematopoietic tumors (22.3\%) and mesenchymal tumors of the skin and soft tissues (19.4\%). Cutaneous hematopoietic tumors comprising the total of 47 cases and mesenchymal tumors of the skin and soft tissues (41 cases) were subjected to detailed histological analysis, as well as immunohistochemical analysis if necessary, and the tumors were classified based on the most recent WHO classification of cutaneous neoplasms. The large number of cutaneous hematopoietic tumors is the result of a large number of mastocytomas and histiocytomas. These tumors were benign in 14 (29.79\%) cases, while the remaining 33 (70.21\%) were malignant. Out of the total number of canine tumors examined based on the biopsy and section materials over the last five years at the Department of Pathology, skin tumors and mammary gland tumors were proved to be the two largest groups diagnosed in $33.4 \%$ and $36 \%$ of cases, respectively. tumors

Key words: cutaneous, dog, haematopoietic, mesenchymal,

\section{INTRODUCTION}

In addition to mammary gland tumors, skin tumors are the second most frequent neoplasms diagnosed in dogs, with predominantly equal incidence of benign and malignant neoplasms (Kaldrymidou et al., 2002; Benjamin et al., 1999; Bostock, 1986). The reason for this high incidence of cutaneous neoplasms partially lies in the fact that the skin is permanently exposed to the influence of physical, chemical and other environmental factors, as well as that the neoplasms are easily recognized as early as in their initial stages (Guzman et al., 2003; Meleo, 1997; Bostock, 1986). Epithelial and melanocytic skin tumors appeared in 
approximately $38 \%$ of cases, while mesenchymal skin tumors appeared in $30 \%$ of cases (Chalita et al., 2001). The age of dogs with diagnosed skin tumors is commonly reported to range widely between 4 months and 16 years, although the average age of these animals is approximately 9 years. (Kaldrymidou et al., 2002).

Valid classification of the cutaneous neoplasms is a basic prerequisite for adequate prognosis and application of the appropriate therapy, which was the basic reason for skin tumor re-classification performed by WHO in 1999. Based on the most recent changes in nomenclature and classification, cutaneous dog tumors were categorized into three groups: a) epithelial and melanocytic skin tumors, b) mesenchymal tumors of the skin and soft tissues and c) hematopoietic tumors (Valli et al., 2002; Goldschmidt et al., 1999; Hendrick et al., 1999). Adequate diagnosis and re-classification of skin tumors is also enabled by application of special staining methods and a wide range of immunohistochemical methods, which, in addition to standard staining methods in the case of certain neoplasms make unavoidable diagnostic methods. Thus, most of the authors use for verification of mastocytoma a staining method that enables visualization of granules in the mastocytes, while grading of the malignancy of these neoplasms is enabled by silver colloid staining and frequently comparative immunohistochemical verification of Ki 67 and PCNA, i.e., cell proliferation antigens (Juntes et al., 2000; Abadie et al., 1999; Gerdes et al., 1992). Immunohistochemical methods are undoubtedly important for immunophenotyping of the intradermal hematopoietic neoplasms, and some of them enable distinguishing of the tumors that primarily developed in the skin from the lymphomas that developed in the lymphatic organs and metastasized into the skin (Moulton, 1990). A large number of monoclonal and polyclonal antibodies are applied in these methods, with a considerable number of them being commercially available - CD3, CD79, mak-387, CD 45, CD5, CD68 etc. (AleksicKovacevic et al., 2001; Greenlee et al., 1990).

Additional reason for our studies was the increasingly frequent number of these neoplasms found over the previous five-year period in our bioptic and section material. The need for retrospective analysis and re-classification of skin tumors is particularly emphasized by the fact that new protocols for treatment of these neoplasms have been introduced and adjusted over the recent years. Therefore, classification based on the latest WHO standards makes the prerequisite for appropriate therapeutic and prognostic approach to the problem.

\section{MATERIAL AND METHODS}

The study included dogs of all breeds and both sexes (123 male dogs and 88 bitches), with their age ranging between 5 months and 15 years. Since the skin is an organ readily accessible to the examiner, the information on localization of cutaneous neoplasms is obtained upon sampling itself. Over the period 1999 2004 , a total of 211 skin tumor specimens were analyzed at the Department of Pathology, Faculty of Veterinary Medicine in Belgrade. Out of this number of skin tumors, 22 cases were diagnosed in 1999, 24 cases in 2000, 38 cases in 2001, 48 
in 2002,51 in 2003 while 28 cases were diagnosed over the first six months of 2004.

The 211 tissue samples were fixed in $10 \%$ neutral buffered formalin and embedded in paraffin. Following the usual rehydration procedure, H\&E staining, Toluidine Blue, Silver colloid staining (AgNOR) and in some cases immunostaining, peroxidase anti peroxidase -PAP method, were performed on 3 to $5 \mathrm{~mm}$ thick sections.

Immunohistochemistry: The peroxidase anti peroxidase method PAP was applied to the formaline fixed material using standard procedure for the monoclonal mouse anti human CD79 (Dako M7051) for the B cell lineage, and direct peroxidase DP was used for rabbit-anti human (Dako, U0026) CD3 antigens on T lymphocytes in cutaneous lymphomas.

\section{RESULTS}

Out of the total of 632 tumor specimens from dogs of different breeds subjected to pathohistological examinations over the period from 1999 till mid2004 (66 months), cutaneous tumors were diagnosed in 211 cases, i.e., in 123 (58.3\%) male animals and 88 (41.7\%) bitches, aged on average 7 years, (ranging from 5 months to 15 years). Based on final diagnosis out of 211 cutaneous neoplasms 113 (53.55\%) were malignant, while 98 (46.44\%) were benign tumors. In the studied material the total of 32 types of cutaneous neoplasms were identified, out of which epithelial and melanocytic tumors were the most predominant $(58.29 \%)$, followed by hematopoietic tumors $(22.27 \%)$ and mesenchymal skin and soft tissue tumors (19.43\%).

The second largest group of skin tumors was the group of hematopoietic tumors comprising the total of 47 cases (22.27\% of all skin tumors). Such a large number of these neoplasms is the result of a large number of mastocytomas and histiocytomas. Five types of neoplasms localized in the skin (Table 1.) were diagnosed within the above group. Mastocytomas, histiocytomas, malignant histiocytomas, cutaneous lymphomas and plasmocytomas were detected in dogs whose age ranged from 5 months to 12 years i.e. 6.5 years on average. In our opinion, breed-related predisposition was present in: German Boxer, mix breed, Labrador Retriever, Rottweiler and Giant Schnauzer, in whom $13(27.66 \%)$ tumors were located on the limb skin, 12 (25.53\%) on the trunk skin, $9(19.15 \%)$ on the head and neck skin, while in 13 (27.66\%) cases the information on location was lacking. This tumos were benign in 14 (29.79\%) cases, while the remaining 33 (70.21\%) were malignant.

Mast cell tumors are malignant tumors composed of diversely differentiated mastocytes. They are most frequently found on the limb skin, followed by trunk, head and neck skin. Based on our observations, the following breeds are predisposed: Boxer, Golden Retriever, Labrador retriever, mix breed and Rottweiler. Out of the total number of 21 cases, 15 (71.43\%) were male dogs while $6(28.57 \%)$ were bitches. The average age of the affected dogs was approximately 7.17 years. Mastocytomas malignancy is graded in three groups based on AgNORs expression, grade I mastocytomas with 2.11-2.61 AgNORs per cell, 
grade II mastocytomas with 3.10-3.38 AgNORs per cell and grade III mastocytomas with 4.71-5.65 AgNORs per cell.

Canine cutaneous histiocytoma is defined as solitary, well-demarcated, spontaneously regressing "round cell tumor" frequently found on the skin of young dogs. The average age of dogs from our study was approximately 5.5 years. The following breeds are predisposed to this type of tumor: Rottweiler, Doberman, Cocker Spaniel, Boxer and Labrador Retriever. The tumors were most frequently located on the trunk skin, followed by head and neck skin, while limb skin was affected only in two cases. Out of the total of 14 cutaneous histiocytomas, 10 (71.43\%) were found in male dogs while 4 (28.57\%) were found in female dogs.

Table 1. Incidence of cutaneous hematopoietic tumors at the Department of Pathology over the period 1999-2004

\begin{tabular}{|l|c|c|}
\hline Tumor & Number & \% out of all skin tumors \\
\hline \hline Cutaneous haematopoetic tumors & 47 & $22,27 \%$ \\
\hline Mast cell tumors & 21 & $9,95 \%$ \\
\hline Canine cutaneous histiocytoma & 14 & $6,63 \%$ \\
\hline Cutaneous lymphoma & 7 & $3,32 \%$ \\
\hline Cutaneous plasmocytoma & 3 & $1,42 \%$ \\
\hline Malignant histiocytoma & 2 & $0,95 \%$ \\
\hline
\end{tabular}

Malignant histiocytoma is a multicentric tumor composed of pleomorphous atypic histiocytes. As for our material, it was diagnosed in one English setter male dog and a mix-breed bitch aged 10 years.

Cutaneous lymphoma may develop as a solitary mass, however it develops more frequently as multiple nodular tumor affecting all parts of the body, particularly in young dogs, and thus, the average age of the dogs was 5 years. Skin biopsies based on which lymphomas were diagnosed were obtained from a Basset, Giant Schnauzer, French bulldog, Boxer and Pekingese (5 female i 2 male dogs). Lymphocyte population in the cutaneous lymphomas was CD3 positive.

Cutaneous plasmocytoma is a malignant tumor of plasma cells. It has been diagnosed in 3 cases, including 10 years old German Shepherd, Alaskan Malamute, also 10 years old, as well as in an 8-year old Pekingese. These tumors are usually solitary, located on the head, body and limb skin.

Mesenchymal tumors of the skin and soft tissues were diagnosed in 41 cases (19.43\% of all skin tumors) which included 10 tumor types. The following tumors were most frequently found: lipomas, fibrosarcomas, hemangiomas, fibromas and liposarcomas (Table 2). These tumors were frequent in the bioptic material obtained from mix breed dogs, Rottweilers, German Shepherds, Dobermans and Epagneul Bretons (French Brittany), and the samples originated from the limb skin ( 10 cases or $35 \%$ ), body skin (9 cases or $22.5 \%$ ), head and neck skin ( 5 cases or $12.5 \%$ ), anal and paraanal region skin (2 cases or $5 \%$ ), while the 
location was unknown in 10 cases (25\%). Age of the dogs ranged between 1 and 13 years, i.e. 7 years at the average. Out of the total number of tumors, $15(37.5 \%)$ were malignant, and 25 (62.5\%) were benign.

Lipoma - the total of 15 specimens were well-demarcated subcutaneous tumors located on the trunk while two specimens were obtained from the anal region. They are frequent in Rottweilers, mix breed dogs, Dobermans, Giant Schnauzers and Epagneul Bretons (French Brittany) at approximately 6.5 years of age. Out of 15 cases, 11 (73.33\%) were female dogs while $4(26.67 \%)$ were male dogs. Fibrolipomas were diagnosed in four cases.

Liposarcoma was diagnosed in 2 cases: in a 10-year old Romanian shepherd dog and a female Rottweiler aged 5 years. In both cases it was located in the trunk subcutis.

Fibroma was diagnosed in two Rottweilers, a male dog 1.5 year of age and a bitch aged 9 years.

Fibrosarcoma was evidenced on the limb skin and head and neck skin, as well as on the trunk skin only in one case in mix breed dog, German shepherd dogs, Rottweilers, Dobermans and Great Dane. The average age of the dogs was 6.22 years. Out of 11 cases, 6 were evidenced in bitches and 5 in male dogs.

Table 2. Incidence of mesenchymal tumors of the skin and soft tissues diagnosed at the Department of Pathology over the period 1999-2004

\begin{tabular}{|l|c|c|}
\hline Tumor & Number & \% out of all skin tumors \\
\hline \hline $\begin{array}{l}\text { Mesenchymal tumors of the skin } \\
\text { and soft tissues }\end{array}$ & 41 & $19,43 \%$ \\
\hline Lipoma/Fibrolipoma & 15 & $7,11 \%$ \\
\hline Fibrosarcoma & 11 & $5,21 \%$ \\
\hline Hemangioma & 6 & $2,84 \%$ \\
\hline Fibroma & 2 & $0,95 \%$ \\
\hline Liposarcoma & 2 & $0,95 \%$ \\
\hline Fibromyxoma & 1 & $0,47 \%$ \\
\hline Myxosarcoma & 1 & $0,47 \%$ \\
\hline Canine hemangiopericytoma & 1 & $0,47 \%$ \\
\hline Calcinosis circumscripta & 1 & $0,47 \%$ \\
\hline Traumatic neuroma & 1 & $0,47 \%$ \\
\hline
\end{tabular}

Hemangioma is a benign tumor of the well-differentiated endothelial cells that form vascular canals. It was evidenced in the following breeds: German shepherd, Epagneul Breton (French Brittany) and American Staffordshire, with the average age of the dogs being 7 years. It was equally distributed in male and female dogs. 


\section{DISCUSSION}

Canine cutaneous tumors are increasingly frequent and are a severe problem encountered in the pathology of this animal species. Information on frequency and appearance of individual cutaneous tumors helps the clinicians to recognize them in time, perform appropriate sampling and, after obtaining of the results of histopathological and immunohistochemical analyses, give correct prognosis and determine a therapy as effective as possible. The skin is the organ that is permanently exposed to the influence of physical, chemical and other environmental factors, and it is readily accessible to clinical examinations, which are some of the reasons for more frequent diagnosis of cutaneous neoplasms (Meleo, 1997; Bostock, 1975). Out of the total number of tumors examined over the previous 66 months at the Department of Pathology, skin tumors are found to be the second most frequent neoplasms with the incidence of $33.4 \%$, preceded only by mammary gland tumors $(36 \%)$, which is consistent with the findings of other authors (Benjamin et al. 1999). However, some other authors reported that these tumors are the most frequent with an incidence of 1,437 cases per 100,000 dogs per year (Dobson et al., 2002). Based on the most recent classification of canine cutaneous tumors developed by WHO in 1999 (Valli et al., 2002; Goldschmidt et al., 1999; Hendrick et al., 1999), skin tumors found in our material were categorized in 3 groups. In our bioptic and section materials, epithelial and melanocytic skin tumors were the most frequent (58.75\%). As for the incidence, the above tumors are followed by hematopoietic system tumors located in the skin (22.27\%) and mesenchymal skin and soft tissue tumors (18.95\%). The above frequencies differ from the results reported by other authors (Kaldrymidou et al., 2002; Chalita et al., 2001).

According to the final diagnosis, out of the total of 211 cutaneous neoplasms, $113(53.55 \%)$ were malignant, while 98 (46.44\%) were benign, however, based on the findings reported by Kaldrymidou et al. (2002) malignant cutaneous tumors accounted for $46.6 \%$, while benign tumors accounted for $53.4 \%$.

The particularly interesting finding is related to the comparative analysis of onset of the most frequent cutaneous neoplasms, i.e., representatives of all three groups both in the world and in our country. Our study results on the frequency of individual tumors (mastocytoma, lipoma, histiocytoma, squamous cell carcinoma, etc.) do not deviate significantly from the findings reported by the authors for the region of Greece (Kaldrymidou et al., 2002), USA (Brodey, 1970), Australia (Finnie and Bostock, 1979; Rothwell et al., 1987) and Great Britain (Bostock, 1986).

The second largest group of the skin tumors was the group of hematopoietic tumors comprising a total of 47 cases (22.27\% of all skin tumors). Such large number of these neoplasms is the result of a large number of mastocytomas and histiocytomas. Five types of neoplasms localized in the skin were diagnosed within the above group. Mastocytomas, histiocytomas, malignant histiocytomas, cutaneous lymphomas and plasmocytomas were detected in dogs whose age ranged from 5 months to 12 years i.e. 6.5 years at the 
average. In our opinion, breed-related predisposition was present in: German Boxer, mix breed, Labrador Retriever, Rottweiler and Giant Schnauzer, in whom 13 $(27.66 \%)$ tumors were located on the limb skin, $12(25.53 \%)$ on the trunk skin, 9 $(19.15 \%)$ on the head and neck skin, while in $13(27.66 \%)$ cases information on the location was lacking. Similary to the other findings these tumors were benign in $14(29.79 \%)$ cases, while the remaining 33 (70.21\%) were malignant. (Kaldrymidou et al., 2002.)

Upon diagnosis of the cutaneous lymphomas it is necessary to distinguish those that have primarily developed in the skin from the lymphomas that developed in the lymphatics and metastasized in the skin. Valid diagnosis and classification of lymphomas is enabled by numerous lymphocyte markers, out of which, the majority of those used in our study are commercially available (AleksićKovacević et al., 2001; Greenlee et al., 1990). Application of immunohistochemical methods enables immunophenotyping of the neoplasms, which essentially determines prognosis and further treatment of the disease. The same applies to our material as well. Out of the total number of 7 intradermal hematopoietic neoplasms, all 7 CD3 positive T lymphomas were evidenced immunohistochemically, while among the total number of the hematopoietic neoplasms, CD79 positive B lymphomas were the most predominant. The reference literature suggests that animals with $B$ cell neoplasms have longer survival period (Valli et al., 2002; Greenlee et al., 1990).

Based on the all above-mentioned, it may be concluded that canine cutaneous tumors are increasingly frequent and severe problem encountered in the pathology of this animal species. Carrying out of our study was driven by the increasingly frequent finding of these neoplasms over the previous five-year period in our bioptic and section materials. The need for retrospective analysis and re-classification of the cutaneous tumors is particularly emphasized by the fact that new protocols for treatment of these neoplasms are being introduced and adjusted over the last years. Therefore, the classification based on the latest WHO standards makes the prerequisite for appropriate therapeutic and prognostic approach to the problem.

ACKNOWLEGMENTS:

This paper was supported by grant 1659 from the Ministry of Science and Technology of the Republic of Serbia.

Address for correspondence:

Sanja Aleksić-Kovacević

Department of Pathology,

Faculty of Veterinary Medicine,

University of Belgrade

Bulevar JA 18, 11000 Beograd,

Serbia and Montenegro

E-mail: skovacevic@vet.bg.ac.yu 


\section{REFERENCES}

1. Abadie JJ, Amardeilh MA, Delverdier ME, 1999, Immunohistochemical detection of proliferating cell nuclear antigen and Ki-67 in mast cell tumors from dogs, J Am Vet Med Assoc, 215,11, 1629-34.

2. Aleksic-Kovacevic S, Jelesijevic $T$, 2001, Morphological, histopathological and immunohistochemical study of canine malignant lymphoma, Acta veterinaria, 4, 245-54.

3. Benjamin SA, Lee AC, Saunders WJ, 1999, Classification and behavior of canine mammary epithelial neoplasms based on life-span observations in beagles, Vet Pathol, 36, 423-36.

4. Bostock DE, 1986, Canine and feline mammary tumors, Br Vet J, 142, 506-15.

5. Bostock DE, 1986, Neoplasms of the skin and subcutaneous tissues in dogs and cats, Br Vet J, 142, $1-19$.

6. Bostock DE, Owen LN, 1975, The skin and adnexa, In: Neoplasia in the cat, dog and horse, Wolfe Medical Publications Ltd., Smeets-Weert, Holand, 15-47.

7. Brodey RS, 1970, Canine and feline neoplasia, Adv Vet Sci Compar Med, 14, 309-54.

8. Chalita MC, Matera JM, Alves MT, Longatto Filho A, 2001, Nonaspiration fine needle cytology and its histologic correlation in canine skin and soft tissue tumors, Anal Quant Cytol Histol, 23, 395-9.

9. Dobson JM, Samuel S, Milstein H, Rogers K, Wood JL, 2002, Canine neoplasia in the UK: estimates of incidence rates from a population of insured dogs, J Small Anim Pract, 43, 240-6.

10. Finnie JW, Bostock DE, 1979, Skin neoplasia in dogs, Aust Vet J, 55, 602-4.

11. Gerdes J, Becker MHG et al., 1992, Immunohistological detection of tumor growth fraction (Ki-67 antigen) in formalin-fixed and routinely processed tissues, J Pathol, 168, 85-6.

12. Goldschmidt MH, Dunstan RW, Stannard AA, Tscharner C et al., 1998, Histological classification of epithelial and melanocytic tumors of the skin of domestic animals, second edition, WHO, Armed Forces Institute of Pathology and American Registry of Pathology, Washington D.C.

13. Greenlee PG, Filippa DA, Quimby FW et al., 1990, Lymphomas in dogs, A morphologic, immunologic and clinical study, Cancer, 66, 480-90.

14. Guzman E, Langowski JL, Owen-Schaub L, 2003, Mad dogs, Englishmen and apoptosis: The role of cell death in UV-induced skin cancer, Apoptosis, 4, 315-25.

15. Hendrick MJ, Mahaffey EA, Moore FM, Vos JH, Walder EJ, 1998, Histological classification of mesenchymal tumors of skin and soft tissues of domestic animals, second edition, WHO, Armed Forces Institute of Pathology and American Registry of Pathology, Washington D.C.

16. Juntes $P$, Pogacnik M, 2000, Morphometric analysis of AgNORs in tubular and papillary parts of canine mammary gland tumors, Analytical and Quantitative cytology and histology, 22, 185-92.

17. Kaldrymidou H, Leontides L, Koutinas AF, Saridomichelakis MN, Karayannopoulou M, 2002, Prevalence, distribution and factors associated with the presence and the potential for malignancy of cutaneous neoplasms in 174 dogs admitted to a clinic in Northern Greece, $J$ Vet Med, 49, 87-91.

18. Meleo KA, 1997, Tumors of the skin and associated structures, Vet Clin North Am Small Anim Pract, 27, 73-94.

19. Moulton JE, 1990, Tumors of the Skin and Soft Tissues, In: Tumors in domestic animals, third edition, University of California Press, Ltd. London, 23-75.

20. Rothwell TLW et al., 1987, Skin neoplasms of dogs in Sydney, Aust Vet J, 64, 161-4.

21. Valli VE, Jacobs RM, Parodi AL, Vernau W, Moore PF, 2002, Histological classification of hematopoietic tumors of domestic animals, second edition, WHO, Armed Forces Institute of Pathology and American Registry of Pathology, Washington D.C. 


\title{
RETROSPEKTIVNA ANALIZA MEZENHIMSKIH TUMORA KOŽE I MEKIH TKIVA PASA
}

\author{
ALEKSIĆ-KOVAČEVIĆ SANJA, KUKOLJ V, JELESIJEVIĆ T i JOVANOVIĆ M
}

\section{SADRŽAJ}

Od ukupno 632 neoplazme pasa različitih rasa, pregledanih u poslednjih 66 meseci, tumori kože dijagnostikovani su u 211 slučajeva i to kod $123(58,3 \%)$ mužjaka i 88 (41,7\%) ženki, prosečne starosti od 7 godina. Od ukupno 211 tumora kože, ustanovljena su 32 tipa neoplazmi, od kojih su najzastupljeniji bili epitelni i melanocitni tumori kože $(58,3 \%)$, zatim hematopoezni tumori $(22,3 \%)$ i mezenhimski tumori kože i mekih tkiva $(19,4 \%)$. Kutani hematopoezni tumori, zastupljeni u 47 slučajeva i mezenhiski tumori kože i mekih tkiva (41slučaj), podvrgnuti su detaljnoj histološkoj analizi i po potrebi imunohistohemijskim ispitivanjima i klasifikovani prema najnovijoj WHO klasifikaciji kutanih neoplazmi. Veliki broj kutanih hematopoeznih tumora je posledica brojnih mastocitoma i histiocitoma. Ovi tumori su bili benigni u $14(29,79 \%)$ slučajeva, a preostalih 33 slučajeva $(70,21 \%)$ su bili maligni tumori. Od ukupnog broja tumora pasa ispitanih u okviru biopsijskog i sekcionog materijala u proteklih pet godina na Katedri za patologiju, tumori kože i tumori mlečne žlezde predstavljaju dve najčešće grupe neoplazmi koje dijagnostikovane u 33,4\%, odnosno 36\% slučajeva. 